\title{
MENINGKATKAN HASIL BELAJAR SISWA PADA PENJUMLAHAN DAN PENGURANGAN PECAHAN DENGAN MENGGUNAKAN STRATEGI PEMBELAJARAN BERBASIS MASALAH DI KELAS V B SD NEGERI 200118 SADABUAN PADANGSIDIMPUAN T.A 2014/2015
}

YUSNIAR, S.Pd.

NIP: 196402061984042001.

Email: yusn4222@gmail.com

\begin{abstract}
abstrak
Permasalahan dalam penelitian ini adalah rendahnya hasil belajar matematika siswa pada materi penjumlahan dan pengurangan pecahan. Selama pembelajaran siswa kurang diberikan kesempatan bertanya setelah guru selesai menjelaskan materi pelajaran. Penelitian ini dilakukan dengan tujuan untuk mengetahui peningkatan hasil belajar siswa pada penjumlahan dan pengurangan pecahaan berpenyebut tidak sama dan untuk mengetahui penggunaan strategi pembelajaran berbasis masalah dalam meningkatkan hasil belajar siswa.

Penelitian termasuk jenis Penelitian Tindakan Kelas (PTK). Penelitian dilakukan SD Negeri 200118 Sadabuan Padangsidimpuan. Subjek dalam penelitian ini siswa kelas V B SD Negeri 200118 Sadabuan Padangsidimpuan T.A. 2014/2015 berjumlah 36 orang dengan rincian 14 orang laki-laki dan 22 orang perempuan. Teknik pengumpulan data menggunakan tes hasil belajar dan lembar format observasi. Teknik analisis data yang digunakan adalah analisis data kualitatif dan kuantitatif.

Hasil penelitian menunjukkan adanya peningkatakan hasil belajar siswa dilihat dari rata-rata nilai maupun persentase ketuntasan belajar siswa secara klasikal. Sebelum diberikan tindakan dari hasil pretes diperoleh rata-rata nilai pretes siswa sebesar 39,6 setelah dilakukan tindakan siklus I dari hasil postes diperoleh rata-rata hasil belajar siswa meningkat menjadi sebesar 5997. Kemudian setelah dilakukan perbaikan pada siklus II, dari hasil postes siklus II, rata-rata hasil belajar siswa kembali meningkat menjadi sebesar 74,2. Peningkatan hasil belajar siswa juga tampak dari ketuntasan belajar siswa secara klasikal, peningkatan dari pretes sebesar 38,89\% menjadi 69,4\% pada siklus I dan meningkat menjadi $88,89 \%$ pada siklus II. Pada pertemuan pertama siklus I persentase aktivitas guru sebesar 60,42\% (cukup) dan pada pertemuan kedua siklus I persentase aktivitas guru sebesar $65 \%$ (cukup). Setelah dilakukan perbaikan pada siklus II, kegiatan guru mengalami peningkatan yaitu pada pertemuan pertama siklus II diperoleh persentase sebesar 83,3\% (baik sekali) dan para pertemuan kedua siklus II diperoleh persentase sebesar 91,67\% (baik sekali). Sementara persentase aktivitas siswa selama pertemuan pertama siklus I sebesar $42 \%$ (kurang) dan pada pertemuan kedua siklus I sebesar 45,83\% (kurang). Pada pertemuan pertama siklus II diperoleh persentase sebesar $79,17 \%$ (baik) dan pada pertemuan kedua siklus II diperoleh persentase $87,5 \%$ (baik).

Berdasarkan hasil penelitian tindakan kelas yang telah dilakukan selama 2 siklus dan masingmasing siklus sebanyak 2 kali pertemuan dapat disimpulkan bahwa penggunaan strategi pembelajaran berbasis masalah dapat meningkatkan hasil belajar siswa pada penjumlahan dan pengurangan pecahan di kelas V B SD Negeri 200118 Sadabuan Padangsidimpuan T.A. 2014/2015.
\end{abstract}




\section{PENDAHULUAN}

memperoleh nilai $\geq 60,00$ dan 22 siswa

Matematika merupakan salah satu mata memperoleh nilai $\leq 60,00$. berdasarkan nilai yang pelajaran penting yang ada di Sekolah Dasar. Hal diperoleh siswa, dapat dikatakan bahwa hasil tersebut dikarenakan matematika tidak dapat belajar siswa di kelas V B tergolong rendah.

dipisahkan dari kehidupan sehari-hari.

Berdasarkan data di atas hanya 14 siswa Matematika juga salah satu pelajaran yang yang memperoleh nilai $\geq 60$ atau $39 \%$ siswa saja mempunyai karakteristik yang berbeda dengan yang mendapatkan nilai $\geq 60,00$ sedangkan 22 yang lainnya dimana terdapat pentahapan, siswa atau $61,11 \%$ siswa lagi mendapatkan nilai pengembangan konsep, pelatihan, pemecahan $\leq 60,00$. Menurut pengamatan dan hasil permasalahan, dan penerapan, dalam hal yang wawancara peneliti dengan guru kelas $\mathrm{V} B$, telah ditentukan. Karena mata pelajaran rendahnya hasil belajar siswa disebabkan oleh matematika sangat penting dalam dunia beberapa faktor, antara lain faktor dari siswa pendidikan dalam setiap jenjang. Oleh sebab itu, sendiri, guru dan sumber belajar. Faktor yang siswa harus dapat mempunyai pemahaman, mempengaruhi siswa yaitu sebagai berikut : penguasaan yang baik tentang matematika. siswa tidak konsentrasi pada saat guru Sebagaimana yang dituntut dalam KTSP, yang menjelaskan materi pembelajaran, siswa malas kita gunakan sekarang ini. Berarti kompetensi, belajar matematika (mengerjakan pekerjaan dan kemampuan, harus dimiliki oleh siswa.

James dalam Ruseffendi,

(1992) rumah), hal ini tampak setiap ada tugas rumah, sering mengabaikannya dan hampir setiap tentang logika mengenai bentuk, susunan, tidak mengerjakan pekerjaan rumah. Faktor yang besaran dan konsep-konsep yang saling mempengaruhi dari guru yaitu, guru sering berhubungan satu sama lainnya dengan jumlah memulai proses belajar mengajar dengan yang banyak". Matematika tumbuh dan menjelaskan, tanpa memberikan kesempatan berkembang karena proses berpikir, oleh karena terlebih dahulu kepada siswa untuk berpikir atau itu logika adalah dasar untuk terbentuknya matematika.

Siswa di sekolah dasar sebaiknya menemukan sendiri. Faktor yang mempengaruhi dari sumber belajar yaitu siswa hanya memiliki memahami semua aspek yang ada pada referensi yang lain yang dimiliki oleh siswa dan kurikulum mulai dari bilangan, geometri dan siswa belum memiliki Lembar Kerja Siswa pengukuran serta pengolahan data. Standar (LKS). Menurut pengakuan guru, guru sudah kompetensi matematika yang sebaiknya dikuasai berupaya semaksimal mungkin untuk siswa SD kelas V B Semester II dalam aspek meningkatkan hasil belajar siswa, tapi tetap saja bilangan adalah menggunakan pecahan dalam hasil belajar siswa rendah.

pemecahan masalah, sedangkan kompetensi Strategi pembelajaran berbasis masalah dasarnya adalah sebagai berikut : 1) Mengubah merupakan pembelajaran yang mengaktifkan pecahan ke bentuk persen dan desimal serta siswa dalam berpikir, jadi bukan guru saja sebaliknya, 2) Menjumlahkan dan mengurangkan sebagai pusat informasi, siswa mempunyai hak berbagai bentuk pecahan, 3) Mengalikan dan dalam menentukan keberhasilannya dalam membagi berbagai bentuk pecahan, 4) belajar. Siswa dapat belajar sendiri dengan Menggunakan pecahan dalam masalah bantuan sumber belajar dan bantuan guru, guru perbandingan dan skala. dalam pembelajaran ini bertindak sebagai

Masalah yang peneliti dapatkan di kelas $\mathrm{V}$ fasilitator dan motivator.

B dalam pembelajaran matematika yaitu Ratumanan dalam Trianto (2009) mengenai rendahnya hasil belajar siswa. Hasil menyatakan "pembelajaran berbasis masalah belajar siswa dalam matematika di kelas V B ini merupakan pendekatan yang efektif untuk masih jauh dari apa yang diharapkan dan masih pengajaran proses berpikir tingkat tinggi, di bawah kriteria minimum $(\leq 60,00)$. Pada saat pembelajaran ini membantu siswa untuk guru mengadakan tes mengenai penjumlahan memproses informasi yang sudah jadi dalam pecahan berpenyebut tidak sama, hasil belajar benaknya dan menyusun pengetahuan mereka siswa tergolong rendah. Jumlah keseluruhan sendiri tentang dunia sosial dan sekitarnya".

siswa kelas V B SD Negeri 200118 Sadabuan Berdasarkan kenyataan di atas maka Padangsidimpuan adalah 36 siswa, dari hasil tes peneliti / guru merasa penting untuk meneliti diperoeh data sebagai berikut : 14 siswa dengan judul "Meningkatkan Hasil Belajar Siswa 
Pada Penjumlahan dan Pengurangan Pecahan 59,97. Selanjutnya dari 36 orang siswa, terdapat dengan Menggunakan Strategi Pembelajaran 25 orang 69,4\% siswa yang dinyatakan tuntas Berbasis Masalah di Kelas V B SD Negeri belajar karena memperoleh nilai $\geq 60$, sedangkan 200118 Sadabuan Padangsidimpuan T.A. sebanyak 11 orang atau 30,56\% masih 2014/2015".

\section{METODE PENELITIAN} dinyatakan belum tuntas karena memperoleh nilai kurang dari 60 (KKM mata pelajaran matematika SD Negeri 200118 Sadabuan Padangsidimpuan). Dari hasil tersebut dapat disimpulkan bahwa ada

Jenis Penelitian yang akan dilaksanakan adalah Pendidikan Tindakan Kelas (PTK) yang berupaya bertujuan untuk memperbaiki proses belajar mengajar dan meningkatkan hasil belajar siswa pada penjumlahan dan pengurangan pecahan melalui strategi Pembelajaran Berbasis Masalah. Penelitian Tindakan yang dilaksanakan ini hanya dilakukan dalam satu kelas.

\section{HASIL PENELITIAN DAN PEMBAHASAN}

\subsubsection{Hasil Pretest}

Berdasarkan hasil penelitian, diperoleh jumlah nilai pretes seluruh siswa sebesar $38,89 \%$ dengan rata-rata nilai pretes 39,6 . Selanjutnya dari 36 orang siswa, hanya 14 siswa yang dinyatakan tuntas karena memperoleh nilai diatas dari 60 (KKM mata pelajaran matematika SD Negeri 200118 Sadabuan Padangsidimpuan). Dari hasil tersebut dapat disimpulkan bahwa pengetahuan awal siswa tentang materi penjumlahan dan pengurangan pecahan di kelas V B SD Negeri 200118 Sadabuan Padangsidimpuan masih sangat rendah yaitu ketuntasannya adalah $38,89 \%$. Oleh karena itu perlu dilakukan tindakan siklus I dengan menggunakan strategi pembelajaran berbasis masalah untuk meningkatkan hasil belajar matematika siswa.

\subsubsection{Postest Siklus I}

Setelah semua materi diajarkan selama dua kali pertemuan, selanjutnya dilakukan ulangan dengan memberikan postes kepada siswa untuk mengetahui perkembangan hasil belajar siswa tentang materi penjumlahan dan pengurangan pecahan yang berpenyebut tidak sama. Postes yang diberikan sama dengan pretes sebanyak 10 soal dalam bentuk uraian atau essai. Jumlah siswa yang mengikuti tes sebanyak 23 siswa. Setelah dilakukan analisis terhadap jawaban-jawaban siswa.

Berdasarkan penelitian, diperoleh jumlah nilai postes siklus I seluruh siswa sebesar 2159 dengan rata-rata nilai postes siklus I sebesar peningkatan hasil belajar siswa tentang materi penjumlahan dan pengurangan pecahan di kelas V B SD Negeri 200118 Sadabuan Padangsidimpuan dilihat dari rata-rata postes siklus I (rata-rata 59,97) dibandingkan sebelum diberikan tindakan atau pretes (rata-rata 38,6). Namun dari jumlah siswa yang dinyatakan tuntas belajar (nilai $\geq 60$ ) yaitu hanya 25 orang atau $69,4 \%$ dan masih kurang dari $75 \%$, maka secara klasikal siswa dinyatakan masih belum mencapai ketuntasan dalam belajar. Oleh karena itu masih perlu dilakukan perbaikan tindakan pada siklus II dengan tetap menggunakan strategi pembelajaran berbasis masalah untuk lebih mengoptimalkan peningkatan hasil belajar matematika siswa.

\subsubsection{Pertemuan Pertama Siklus II}

Pertemuan pertama siklus II juga dilakukan dengan alokasi waktu $2 \times 35$ menit pada sub materi penjumlahan pecahan yang berpenyebut tidak sama dengan tetap menggunakan strategi pembelajaran berbasis masalah. Proses pembelajaran dilaksanakan di ruang kelas V B SD Negeri 200118 Sadabuan Padangsidimpuan. Guru mengawali pembelajaran dengan mengucapkan salam kepada seluruh siswa dilanjutkan dengan mengabsen kehadiran siswa. Jumlah siswa yang hadir sebanyak 36 orang siswa. Kemudian guru mengorientasikan siswa pada masalah dengan melakukan appersepsi tentang penjumlahan pecahan yang berpenyebut tidak sama dengan melakukan tanya jawab bersama siswa. Selanjutnya guru menjelaskan indikator dan tujuan pembelajaran, kemudian memotivasi siswa untuk terlibat aktif pada kegiatan pemecahan masalah.

Pada kegiatan inti, guru mengorganisasikan siswa untuk belajar dengan menjelaskan materi penjumlahan pecahan yang berpenyebut tidak sama dan menjelaskan aturanaturan mengerjakan penjumlahan pecahan yang berpenyebut tidak sama dengan memberikan lebih banyak contoh soal dalam bentuk cerita dan menjelaskan cara penyelesaiannya di papan tulis mulai dari memahami soal yaitu apa yang 
diketahui dan apa yang ditanya, membuatnya ke tidak sama dengan tetap menggunakan strategi dalam model matematika dan menyelesaikan soal pembelajaran berbasis masalah. Proses dengan benar. Guru selanjutnya membentuk pembelajaran dilaksanakan di ruang kelas V B ulang kelompok siswa sebanyak 6 kelompok SD Negeri 200118 Sadabuan Padangsidimpuan. dengan masing-masing kelompok beranggotan 6 Guru mengawali pembelajaran dengan orang siswa. Kemudian guru memberikan mengucapkan salam kepada seluruh siswa beberapa soal cerita kepada tiap kelompok untuk dilanjutkan dengan mengabsen kehadiran siswa. dikerjakan secara bersama-sama. Setelah siswa Jumlah siswa yang hadir sebanyak 36 orang masing-masing kelompok menerima soal yang siswa. Kemudian guru mengorientasikan siswa akan diselesaikan, guru memberikan waktu pada masalah dengan melakukan appersepsi kepada siswa untuk memahami soal-soal yang tentang materi pengurangan pecahan yang sudah diterima siswa kemudian memberikan berpenyebut tidak sama dengan melakukan tanya kesempatan kepada siswa untuk bertanya hal-hal jawab bersama siswa. Selanjutnya guru yang kurang dipahami mengenai soal yang menjelaskan indikator dan tujuan pembelajaran, diberikan. Guru kemudian menjelaskan langkah kemudian memotivasi siswa agar untuk terlibat kerja yang harus dilakukan siswa dalam aktif pada kegiatan pemecahan masalah.

menyelesaikan soal mulai dari memahami soal Pada kegiatan inti, yaitu apa yang diketahui dan apa yang ditanya, mengorganisasikan siswa untuk belajar dengan membuatnya ke dalam model matematika dan menjelaskan materi pengurangan pecahan yang menyelesaikan soal dengan benar. Selanjutnya berpenyebut tidak sama. Kemudian menjelaskan guru membimbing dan memotivasi siswa aturan-aturan mengerjakan pengurangan pecahan melakukan penyelidikan secara kelompok untuk yang berpenyebut tidak sama dengan mengerjakan soal-soal yang diberikan. Selesai memberikan lebih banyak contoh soal dalam mengerjakan soal-soal, guru kemudian bentuk cerita dan menjelaskan cara membimbing siswa untuk menyajikan hasil kerja penyelesaiannya di papan tulis mulai dari kelompoknya dengan meminta perwakilan dari memahami soal yaitu apa yang diketahui dan apa masing-masing kelompok untuk menjawab soal- yang ditanya, membuatnya ke dalam model soal di papan tulis secara bergantian. Guru matematika dan menyelesaikan soal dengan kemudian memberikan kesempatan kepada benar. Kemudian guru memberikan beberapa soal kelompok lainnya untuk memberikan penilaian cerita kepada tiap kelompok untuk dikerjakan atau koreksi pada jawaban atau penyelesaian soal secara bersama-sama. Setelah tiap kelompok yang dikerjakan temannya di papan tulis. Guru menerima soal yang akan diselesaikan, guru juga membimbing siswa untuk saling menghargai memberikan waktu kepada siswa untuk pendapat temannya.

memahami soal-soal yang sudah diterima siswa

Pada kegiatan akhir, guru membimbing kemudian memberikan kesempatan kepada siswa siswa untuk menganalisis dan mengevaluasi untuk bertanya hal-hal yang kurang dipahami proses pemecahan masalah yang telah dilakukan mengenai soal yang diberikan. Guru kemudian siswa dengan melakukan refleksi terhadap menjelaskan langkah kerja yang harus dilakukan penyelidikan dan proses-proses yang digunakan siswa dalam menyelesaikan soal mulai dari selama berlangsungnya pemecahan masalah. memahami soal yaitu apa yang diketahui dan apa Selanjutnya, guru memberikan kesempatan yang ditanya, membuatnya ke dalam model kepada siswa menyampaikan hal penting dalam matematika dan menyelesaikan soal dengan menyelesaikan soal penjumlahan pecahan benar.

berpenyebut tidak sama. Sebelum mengakhiri Selanjutnya guru membimbing dan pembelajaran guru memberikan tugas mandiri memotivasi siswa melakukan penyelidikan secara (PR) kepada siswa. Guru mengakhiri pertemuan kelompok untuk mengerjakan soal-soal yang dengan mengucapkan salam kepada seluruh diberikan. Selesai mengerjakan soal-soal, guru siswa.

\subsubsection{Pertemuan Kedua Siklus II} kemudian membimbing siswa untuk menyajikan hasil kerja kelompoknya dengan meminta perwakilan dari masing-masing kelompok untuk menjawab soal-soal di papan tulis secara

Pertemuan kedua siklus II juga dilakukan bergantian. Guru kemudian memberikan dengan alokasi waktu $2 \times 35$ menit pada sub kesempatan kepada kelompok lainnya untuk materi pengurangan pecahan yang berpenyebut memberikan penilaian atau koreksi pada jawaban 
Volume 3 Nomor 1, Halaman 1-81, Januari--Juni 2018

RISTEKDIK | Jurnal Bimbingan dan Konseling

P-ISSN: 2527-4244, E-ISSN : 2541-206X

atau penyelesaian soal yang dikerjakan temannya di papan tulis. Guru juga membimbing siswa untuk saling menghargai pendapat temannya.

\section{PEMBAHASAN}

Pada kegiatan akhir, guru bersama siswa adanya peningkatan rata-rata nilai hasil belajar menganalisis dan mengevaluasi proses siswa. Sebelum diberikan tindakan dari hasil pemecahan masalah yang telah dilakukan siswa pretes diperoleh rata-rata nilai sebesar 39,6. dengan melakukan refleksi terhadap penyelidikan Setelah dilakukan tindakan siklus I, dari hasil dan proses-proses yang digunakan selama postes siklus I hasil belajar siswa meningkat berlangsungnya pemecahan masalah. menjadi rata-rata nilai sebesar 59,97. Kemudian Selanjutnya, guru memberikan kesempatan setelah dilakukan perbaikan pembelajaran pada kepada siswa menyampaikan hal-hal penting siklus II, dari hasil postes siklus II hasil belajar dalam menyelesaikan soal pengurangan pecahan siswa juga mengalami peningkatan dengan rataberpenyebut tidak sama. Kemudian guru rata nilai sebesar 74,2.Selanjutnya persentase membimbing siswa membuat rangkuman hasil jumlah siswa yang dinyatakan tuntas dan belum pembelajaran yang telah dilakukan. Sebelum tuntas belajar, secara ringkas dirangkum pada mengakhiri pembelajaran, guru memberikan Tabel 18.

tugas mandiri (PR) kepada siswa untuk dikerjakan masing-masing siswa di rumah dan mengingatkan siswa bahwa pada pertemuan berikutnya akan dilakukan ulangan (postes) kedua. Kemudian guru mengakhiri pertemuan dengan mengucapkan salam kepada seluruh siswa.

Berdasarkan Tabel 10, diperoleh jumlah nilai postes siklus II seluruh siswa sebesar 2671 dengan rata-rata nilai postes siklus II sebesar 74,2 . Selanjutnya dari 36 orang siswa, terdapat 32 orang $88,89 \%$ siswa yang dinyatakan tuntas belajar dengan memperoleh nilai $\geq 60$, sedangkan sebanyak 4 orang atau $11,11 \%$ masih dinyatakan belum tuntas karena memperoleh nilai kurang dari 60 (KKM mata pelajaran matematika SD Negeri 200118 Sadabuan Padangsidimpuan). Dari hasil tersebut dapat disimpulkan bahwa ada peningkatan hasil belajar siswa tentang materi penjumlahan dan pengurangan pecahan di kelas V B SD Negeri 200118 Sadabuan Padangsidimpuan dilihat dari rata-rata postes siklus II (rata-rata 74,2) dibandingkan postes siklus I (rata-rata 59,97 maupun sebelum diberikan tindakan atau pretes (rata-rata 39,6). Selanjutnya dari jumlah siswa yang dinyatakan tuntas belajar (nilai $\geq 60$ ) yaitu ada 32 orang atau $88,89 \%$ serta sudah lebih dari $75 \%$, maka secara klasikal siswa dinyatakan telah berhasil mencapai ketuntasan dalam belajar secara kelas. Dengan demikian, penggunaan strategi pembelajaran berbasis masalah terbukti dapat meningkatkan hasil belajar matematika siswa sehingga sudah dianggap cukup dan tidak perlu lagi dilakukan tindakan selanjutnya.

\section{Tabel. 16 \\ Rekapitulasi Persentase Ketuntasan Belajar Siswa}

\begin{tabular}{|c|c|c|c|c|c|c|c|c|}
\hline \multirow{2}{*}{$\begin{array}{l}\mathbf{N} \\
\text { o. }\end{array}$} & \multirow{2}{*}{$\begin{array}{c}\text { Nilai } \\
\text { Ketunt } \\
\text { asan }\end{array}$} & \multicolumn{2}{|c|}{ Pretes } & \multicolumn{2}{|c|}{ Postes I } & \multicolumn{2}{|c|}{ Postes II } & \multirow{2}{*}{$\begin{array}{c}\text { Keteran } \\
\text { gan }\end{array}$} \\
\hline & & $\mathbf{F}$ & $\%$ & $\mathbf{F}$ & $\%$ & $\mathbf{F}$ & $\%$ & \\
\hline 1 & $\begin{array}{c}\text { Nilai < } \\
60\end{array}$ & $\begin{array}{l}2 \\
2\end{array}$ & $\begin{array}{c}61,1 \\
1 \%\end{array}$ & 1 & $\begin{array}{c}30,5 \\
6 \%\end{array}$ & 4 & $\begin{array}{c}11,1 \\
1 \%\end{array}$ & $\begin{array}{l}\text { Belum } \\
\text { tuntas }\end{array}$ \\
\hline 2 & $\begin{array}{c}\text { Nilai } \geq \\
60\end{array}$ & $\begin{array}{l}1 \\
4 \\
\end{array}$ & $\begin{array}{c}38,8 \\
9 \% \\
\end{array}$ & $\begin{array}{l}2 \\
5\end{array}$ & $\begin{array}{c}69,4 \\
\% \\
\end{array}$ & $\begin{array}{l}3 \\
2 \\
\end{array}$ & $\begin{array}{c}88,8 \\
9 \% \\
\end{array}$ & Tuntas \\
\hline & imlah & $\begin{array}{l}3 \\
6\end{array}$ & $\begin{array}{c}100 \\
\%\end{array}$ & $\begin{array}{l}3 \\
6\end{array}$ & $\begin{array}{c}100 \\
\%\end{array}$ & $\begin{array}{l}3 \\
6\end{array}$ & $\begin{array}{c}100 \\
\%\end{array}$ & \\
\hline
\end{tabular}

Berdasarkan Tabel 16, sebelum diberikan tindakan dari hasil pretes menunjukkan yang tuntas dalam belajar terdapat 14 orang atau $38,89 \%$ dan 22 orang atau $61,11 \%$ yang belum tuntas. Pada siklus I dari hasil postes I terdapat 25 orang atau $69,4 \%$ siswa yang telah tuntas dalam belajar sedangkan 11 orang atau 30,56\% siswa yang belum tuntas dalam belajar. Setelah dilakukan siklus II dari hasil postes II, jumlah siswa yang telah tuntas dalam belajar meningkat menjadi 32 orang atau $88,89 \%$ sedangkan siswa yang masih belum tuntas belajar hanya 4 orang atau $11,11 \%$. Dengan demikian berdasarkan hasil tersebut menunjukkan adanya peningkatan persentase atau jumlah siswa yang telah tuntas belajar secara klasikal.

Keberhasilan penggunaan strategi pembelajaran berbasis masalah juga dapat dilihat dari hasil observasi mitra kolaborasi tentang kemampuan guru maupun aktivitas siswa selama proses pembelajaran. Pada pertemuan pertama siklus I persentase aktivitas guru sebesar 60,42\% atau tergolong cukup dan pada pertemuan kedua siklus I persentase aktivitas guru sebesar $65 \%$ atau masih tergolong cukup. Sementara 
persentase aktivitas siswa selama pertemuan selama 2 siklus dan masing-masing siklus pertama siklus I sebesar $42 \%$ atau tergolong sebanyak 2 kali pertemuan dapat disimpulkan kurang dan pada pertemuan kedua siklus I bahwa penggunaan strategi pembelajaran sebesar $45,83 \%$ atau masih tergolong kurang. berbasis masalah dapat meningkatkan hasil

Berdasarkan hasil pengamatan mitra belajar siswa pada penjumlahan dan pengurangan kolaborasi selama tindakan siklus I tampak pecahan di kelas V B SD Negeri 200118 bahwa aktivitas siswa masih tergolong kurang. Sadabuan Padangsidimpuan T.A. 2014/2015.

Selama proses pembelajaran siswa masih kurang termotivasi untuk terlibat dalam pemecahan masalah yang dipilih dan kurang aktif bekerjasama dalam kelompok untuk menyelesaikan soal. Kurangnya aktivitas siswa selama proses pembelajaran menurut catatan mitra kolaborasi dikarenakan selama proses pembelajaran guru kurang membimbing siswa dalam mengerjakan soal, kurang jelas mengajukan pertanyaan (soal), kurang membantu siswa dalam mendefenisikan dan mengorganisasikan tugas belajar yang berhubungan dengan masalah (soal), serta masih
kurang membantu siswa merencanakan dan menyiapkan karya yang sesuai. Oleh karena itu perlu dilakukan perbaikan dan pengembangan pembelajaran pada siklus II.

$$
\text { Setelah dilakukan perbaikan }
$$

pembelajaran pada siklus II, kegiatan guru mengalami peningkatan yaitu pada pertemuan pertama siklus II diperoleh persentase sebesar $83,3 \%$ atau tergolong baik sekali dan para pertemuan kedua siklus II diperoleh persentase sebesar $91,67 \%$ atau tergolong baik sekali. Demikian halnya aktivitas siswa, pada pertemuan pertama siklus II diperoleh persentase sebesar $79,17 \%$ atau tergolong baik dan pada pertemuan kedua siklus II diperoleh persentase sebesar $87,5 \%$ atau tergolong baik. Selama tindakan siklus II, aktivitas siswa dalam mendengarkan penjelasan guru, menyelesaikan soal, dan motivasi siswa untuk terlibat dalam pemecahan masalah yang dipilih sudah tergolong baik sekali. Adanya peningkatan aktivitas siswa juga dikarenakan selama tindakan siklus II, aktivitas guru dalam menjelaskan tujuan pembelajaran, menjelaskan fenomena atau cerita untuk memunculkan masalah, memotivasi siswa untuk terlibat dalam pemecahan masalah, membimbing siswa mengerjakan soal, memberi kesempatan pada setiap kelompok untuk memberikan penilaian terhadap kelompok lain, dan memberi kesempatan siswa menyampaikan hal-hal penting dari penyelesaian soal yang telah dilakukan sudah tergolong baik sekali.

Dengan demikian berdasarkan hasil penelitian tindakan kelas yang telah dilakukan

\section{KESIMPULAN}

Berdasarkan hasil penelitian tindakan kelas yang telah dilakukan selama 2 siklus dan masing-masing siklus sebanyak 2 kali pertemuan dapat disimpulkan bahwa penggunaan strategi pembelajaran berbasis masalah dapat meningkatkan hasil belajar siswa pada penjumlahan dan pengurangan pecahan di kelas V B SD Negeri 200118 Sadabuan Padangsidimpuan T.A. 2014/2015, dengan rincian sebagai berikut:

1. Sebelum diberikan tindakan dari hasil pretes diperoleh rata-rata nilai pretes siswa sebesar 39,6. Dari 36 siswa 22 orang yang tuntas atau $61,11 \%$ dan siswa yang belum tuntas belajar terdapat 14 orang atau $38,89 \%$.

2. Setelah dilakukan tindakan siklus I, dari hasil postes rata-rata hasil belajar siswa meningkat menjadi sebesar 59,97. Dari 36 siswa, terdapat 25 orang $69,4 \%$ siswa yang tuntas belajar sedangkan 11 orang atau 30,56\% masih belum tuntas belajar. Karena jumlah siswa yang tuntas hanya $69,4 \%$ atau kurang dari $75 \%$ maka secara klasikal siswa dinyatakan masih belum mencapai ketuntasan dalam belajar sehingga perlu dilakukan perbaikan tindakan pada siklus II.

3. Setelah dilakukan perbaikan pada siklus II, dari hasil postes rata-rata hasil belajar siswa kembali meningkat menjadi sebesar 74,2. Dari 36 siswa, terdapat 32 orang $88,89 \%$ siswa yang tuntas belajar sedangkan 4 orang atau $11,11 \%$ masih belum tuntas belajar. Karena jumlah siswa yang tuntas sebesar $88,89 \%$ atau lebih dari $75 \%$ maka secara klasikal siswa dinyatakan telah berhasil mencapai ketuntasan dalam belajar. 
Volume 3 Nomor 1, Halaman 1-81, Januari--Juni 2018

RISTEKDIK | Jurnal Bimbingan dan Konseling

P-ISSN: 2527-4244, E-ISSN : 2541-206X

\section{DAFTAR PUSTAKA}

Abdurrahman, Mulyono. 2003. Pendidikan Bagi Anak Berkesulitan Belajar, Jakarta: Rineka Cipta.

Amir, Taupik. 2008. Inovasi Pendidikan Melalui Problem Based Learning, Jakarta: Kencana.

Baharuddin dan Esa Nur Wahyuni. 2007. Teori Belajar dan Pembelajaran, Malang: ArRuzz Media.

Daryanto. 2009. Panduan Proses Pembelajaran Kreatif dan Inovatif, Jakarta: Publisher.

Hamalik, Oemar. 2003. Proses Belajar Mengajar, Jakarta: Bumi Aksara.

Muslich, Mansur. 2009. Melaksanakan PTK Itu Mudah, Jakarta: Bumi Aksara.

Russeffendi, E.T. 1992. Pendidikan Matematika 3 Modul 1- 9, Jakarta: Departemen Pendidikan dan Kebudayaan Proyek Pembinaan Tenaga Kependidikan Pendidikan Tinggi.

Sentyasa, I. Wayan. 2008. Pembelajaran Berbasis Masalah dan Pembelajaran Kooperatif, (online dalam www.freewebs.com/santyasa/.../problem based learning.pdf, Diakses 15 Oktober 2011).

Sudjana, Nana. 2009. Penilaian Hasil Proses Belajar Mengajar, Bandung: Remaja Rosdakarya.

Sutikno, Sobry. 2009. Belajar dan Pembelajaran, Bandung: Prospect.

Trianto. 2009. Mendesain Model Pembelajaran Inovatif Progresif, Jakarta: Kencana Prenada Media Group. 